\title{
Evolution of 5-hydroxymethylfurfural (HMF) and furfural (F) in fortified wines submitted to overheating conditions
}

\author{
V. Pereira ${ }^{a}$, F.M. Albuquerque ${ }^{b}$, A.C. Ferreira $^{c}$, J. Cacho ${ }^{\mathrm{d}}$, J.C. Marques ${ }^{\mathrm{a}, *}$ \\ a Centro de Ciências Exactas e Engenharia, Universidade da Madeira, Campus da Penteada, 9000-390 Funchal, Portugal \\ b Madeira Wine Company, Rua dos Ferreiros, 191, 9000-082 Funchal, Portugal \\ c Escola Superior de Biotecnologia da Universidade Católica Portuguesa, Rua Dr. António Bernardino de Almeida, $4200-072$ Porto, Portugal \\ d Department of Analytical Chemistry, University of Zaragoza, 50009 Zaragoza, Spain
}

\section{A R T I C L E I N F O}

\section{Article history:}

Received 7 June 2010

Accepted 7 November 2010

\section{Keywords:}

Madeira wine

Estufagem

Furfural

5-Hydroxymethylfurfural

\begin{abstract}
A B S T R A C T
As furfural (F) and 5-hydroxymethylfurfural (HMF) are essentially formed from sugar dehydration, especially in food submitted to heat, they can be found in beverages, as well as fortified sweet wines. In order to assess the impact of temperature on Madeira winemaking, three traditional varieties of Madeira wines (Malvasia, Sercial and Tinta Negra Mole) were studied to evaluate the F and HMF contents. The wines were produced by two vinification processes, following traditional and modern methodologies, heated at standard conditions ( $30^{\circ} \mathrm{C}$ and $45^{\circ} \mathrm{C}$, for 4 months) and compared with the same wines submitted to overheating conditions ( $55^{\circ} \mathrm{C}$, for 4 months). The RP-HPLC-DAD methodology used for the control of $\mathrm{F}$ and HMF during the process showed no significant changes in the wines maintained at $30^{\circ} \mathrm{C}$ (canteiro) and a noticeable but controlled increase in the wines heated at $45^{\circ} \mathrm{C}$ (estufagem) where values up to about $150 \mathrm{mg} / \mathrm{L}$ of HMF could be found in sweet wines. The strong relation of this compound with the sugar content and baking temperature stood out in the wines submitted to overheating conditions where values higher than $1 \mathrm{~g} / \mathrm{L}$ could be found for sweeter wines, with HMF level being in general higher than $\mathrm{F}$.

The results clearly suggest that the amount of HMF in these fortified wines can be easily controlled when submitted to adequate conditions of heating during estufagem and storage. Furthermore, different temperatures for the baking of sweet and dry wines may be considered.
\end{abstract}

(c) 2010 Elsevier Ltd. All rights reserved.

\section{Introduction}

Madeira wines are classified as fortified, with alcoholic strengths between 17 and $22 \%(\mathrm{v} / \mathrm{v})$ and sweetness levels ranging from 0 (dry) up to about $130 \mathrm{~g} / \mathrm{L}$ (sweet). Fermentation is carried out according to both the grape variety involved and the type of wine being produced (dry, medium dry, medium sweet and sweet). Malvasia and Sercial grapes are two of the traditional white varieties used for the preparation of high quality sweet and dry wines, respectively and Tinta Negra Mole is a red grape versatile variety, being used for the production of different types of Madeira. Sweet wines, traditionally not fermented, are currently obtained by a partial fermentation, in order to ensure $4 \%$ of alcohol exclusively derived from alcoholic fermentation and maintaining the high content of residual sugars. In contrast, Madeira dry wines can be completely fermented to sugar levels close to $0 \mathrm{~g} / \mathrm{L}$ (traditional method) or be fermented to low sugar levels (less than $1.5^{\circ} \mathrm{Be}$ ). Modern vinification techniques, following recent studies carried out to improve the typicity characteristics

\footnotetext{
* Corresponding author. Tel.: +351 291705103; fax: +351291705149. E-mail address: marques@uma.pt (J.C. Marques).
}

(Oliveira e Silva et al., 2008), have been introduced with the purpose of stabilizing the total sugar content in sweet wines to about $80 \mathrm{~g} / \mathrm{L}$ and maintaining some residual sugars in dry wines. When the required sweetness level is attained the fermentation is stopped by the addition of a natural grape spirit (containing 95\% (v/v) of ethanol). Then, two ageing processes can be followed: the canteiro, usually applied to the finest wines, namely those produced from Malvasia and Sercial grapes, where the wines are maintained under mild heating storage conditions (heating rooms not exceeding $30^{\circ} \mathrm{C}$ ); and the estufagem, where the wines are heated to about $45^{\circ} \mathrm{C}$ up to 3 months. The Tinta Negra Mole red variety, the most prolific variety in Madeira, used for the production of wines with different sweetness, is usually submitted to the practice of estufagem before undergoing a normal maturation process in oak casks for a minimum period of 3 years. During the heating stage, a premature ageing process occurs, originating the typical colour and bouquet of these wines and contributing to their exceptional longevity.

The current concern with the alimentary quality increases the necessity for the use of chemical markers, which evaluate possible damages in the foodstuffs submitted to overheating and drawn out storage. The heating process can be used advantageously to preserve foods, destroying the spoilage organisms, but holding back the 
nutritional and organoleptic properties. In the case of Madeira wines, the heating process, used in the preparation of these wines since the 18th century, is generally associated with the toasted aroma and typical brownish colour. Among the aromas formed during this period (Oliveira e Silva et al., 2008), the current study has focused its attention on the formation of two furanic compounds, furfural $(\mathrm{F})$ and 5-hydroxymethylfurfural (HMF). These are the main degradation products of carbohydrates and their occurrence in foods is generally related to non-enzymatic browning reactions, namely Maillard type reactions (MR), sugar degradation in acid medium and caramelization (Antonelli, Chinnici, \& Masino, 2004; Granados, Mir, Serrana, \& Martinez, 1996). Indeed, they are currently used as heat-treatment markers of foods.

In acidic medium, the heating of pentoses and hexoses originates $\mathrm{F}$ and $\mathrm{HMF}$, respectively, after a slow enolization and a fast $\beta$-elimination of three water molecules (Belitz, Grosch, \& Schieberle, 2009). Indeed, the acid-catalysed degradation mechanism of fructose and glucose produces in a first step 1,2- or/and 2,3-enediolic intermediates, which rapidly eliminates water molecules before producing HMF (see Fig. 1, adapted from Antonelli et al. (2004)). At wine pH (about 3.5) the formation route for $\mathrm{F}$ and $\mathrm{HMF}$ in Madeira wines can be explained almost entirely by acid-catalysed sugar degradation, since Maillard chemistry is not favoured in the acidic media. The analytical control of $\mathrm{F}$ and HMF has received some importance and its occurrence has been reported in several food products, including fruit juices (Gökmen \& Acar, 1999), beers (Lo Coco, Valentini, Novelli, \& Ceccon, 1995), brandies (Granados et al., 1996) and fortified wines (Cutzach, Chatonnet, \& Dubourdieu, 1999; Ho, Hogg, \& Silva, 1999). From a safety perspective and for food quality assurance, HMF legal limits were already issued for some foodstuffs, namely for concentrated rectified grape must: EC Regulation No. 1493/99 sets up a limit of 25 ppm (Falcone, Tagliazucchi, Verzelloni, \& Giudici, 2010). The F content is also useful as an off-flavour indicator and HMF is frequently correlated with browning reactions (Lo Coco et al., 1995).

Being essentially considered as indicators of overheated foodstuff, the presence of HMF and $\mathrm{F}$ in foods has raised some toxicological concerns in recent years. Some authors considered that they are natural components of traditional foods, posing no risk to human health (Adams et al., 1997; Janzowski, Glaab, Samimi, Schlatter, \& Eisenbrand, 2000), while others say that HMF can be poisonous to the nervous system due to accumulation in the body when combined with proteins, eventually causing damages in the muscles and viscera (Li \& Lu, 2005). HMF derivatives, such as 5-chloromethyl- and

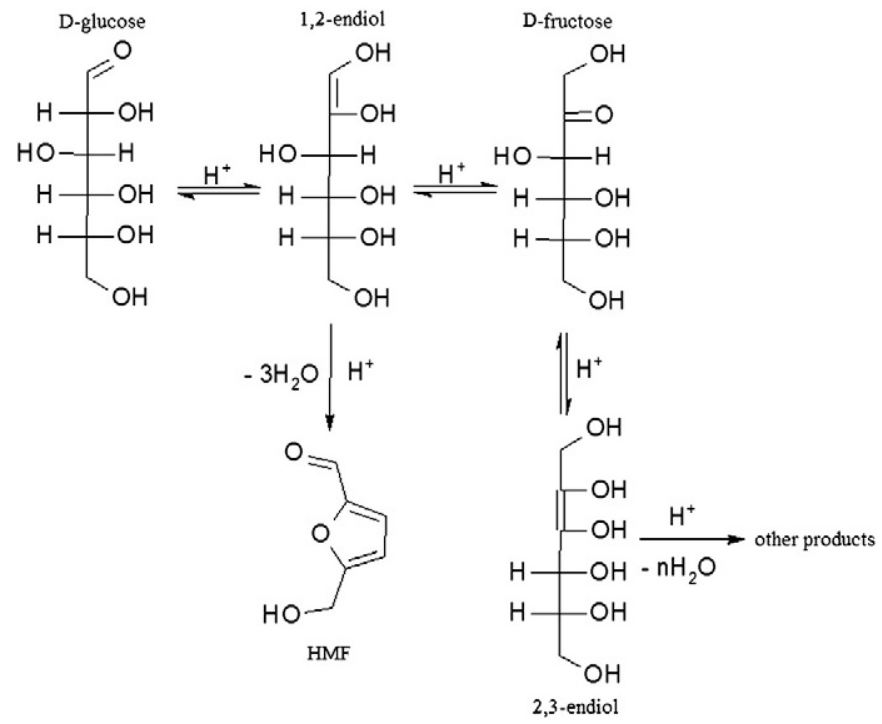

Fig. 1. HMF formation pathway by sugar acid-catalysed dehydration (adapted from Antonelli et al. (2004)). 5-sulfoxymethylfurfural (SMF), have been associated with cytotoxic, genotoxic, and tumoral effects (Nassberger, 1990; Surh, Liem, Miller, \& Tannenbaum, 1994; Zhang et al., 1993). In recent studies, special attention has been given to HMF-related carcinogenicity (Monien, Frank, Seidel, \& Glatt, 2009; Durling, Busk, \& Hellman, 2009).

The growing attention of the scientific community towards the potentially toxic effects of HMF and $\mathrm{F}$ has triggered the current interest on the formation of these compounds in Madeira wines, especially because sweet wines have a rather high content of carbohydrates and are submitted to a quite long heating process (at least 3 months).

The study was focused on their determination in wines with different sweetness levels, produced under diverse fermentation and heating conditions, in order to simulate different ageing processes. To do so, three traditional varieties of Madeira wines, Malvasia, Sercial and Tinta Negra Mole, were produced by two different vinification processes and heated under overheating conditions (at $55^{\circ} \mathrm{C}$ for 4 months), and compared with wines submitted to standard heating conditions ( 30 and $45^{\circ} \mathrm{C}$ ). $\mathrm{F}$ and HMF levels were determined by direct RP-HPLC-DAD analysis of the wines under study.

\section{Experimental}

\subsection{Reagents}

HMF and F analytical standard-grade (both with assay $>98 \%$ ) were obtained from Acros Organics (Geel, Belgium). D-fructose and D- $(+)-$ glucose were supplied by Himedia (Mumbai, India) with assays higher than 99\%. The hydroalcoholic solutions were prepared with ethanol (96\%) from Sigma-Aldrich (St. Louis, MO, USA) and ultra-pure water (Milli-Q System, Millipore, Bedford, MA, USA). The chromatographic mobile phases were prepared with ultra-pure water, methanol HPLC grade (Sigma-Aldrich, St. Louis, MO, USA) and acetic acid (JMGS, Portugal, $>99 \%$ ). All solvents used were previously filtered through $0.45 \mu \mathrm{m}$ membranes from Pall Corporation (Ann Arbor, MI, USA) to remove any impurities.

\subsection{Wines}

Traditionally, the vinification process of sweet Madeira wines used to be characterized by short fermentative steps or even by its absence, originating wines with high sugar levels, whereas dry Madeira wines used to be completely fermented (traditional methods). Nowadays, there is a tendency to extend the fermentation of sweet wines (lowering the amount of residual sugars) and shorten the fermentation of dry wines (modern methods).

For the purpose of the present study, about $600 \mathrm{~L}$ of must was obtained from Malvasia grapes (2003 harvest) and equal amounts were fermented according to different methods: traditional and modern. One was almost not fermented, the Malvasia traditional wine $(M \mathrm{t})$, containing $125 \mathrm{~g} / \mathrm{L}$ of residual sugars. The other one was slightly fermented ( 4 days at $21^{\circ} \mathrm{C}$ ), getting a sugar level of about $78 \mathrm{~g} / \mathrm{L}$, denominated as Malvasia modern wine $(\mathrm{Mm})$. The same procedure was applied to produce sweet wines from Tinta Negra Mole grapes: Tinta Negra Mole modern sweet (TmS) and Tinta Negra Mole traditional sweet (TtS). Two Sercial wines (equal amounts) were produced from $600 \mathrm{~L}$ of must. One was fermented until complete transformation of sugars (Sercial traditional, St). The other was fermented maintaining a low level of residual sugars (Sercial modern, Sm). Similarly, Tinta Negra Mole was used for the production of two dry wines: Tinta Negra Mole modern dry (TmD) and Tinta Negra Mole traditional dry (TtD). All wines were industrially elaborated in stainless steel tanks of local Madeira wine-producing cellars and the alcoholic fermentation was carried out by indigenous yeast under controlled temperature and malolactic fermentation was not encouraged. Sulphite was added to musts up to $150 \mathrm{mg} / \mathrm{L}$. After vinification, all wines were placed in stainless steel vats and heated at three 
different temperatures, 30,45 and $55^{\circ} \mathrm{C}$, for 4 months. For the purposes of the study, Sercial and Malvasia musts were also processed by the modern methods to obtain a sweet (Sercial modern sweet, $\mathrm{SmS}$ ) and a dry wine (Malvasia modern dry, $\mathrm{MmD}$ ), respectively, being heated at $45^{\circ} \mathrm{C}$ during the same period. As Malvasia is almost exclusively used for sweet wines and Sercial for dry wines, this experiment was carried out in order to allow for a comparison between both varieties when submitted to the same fermentation and heating processes.

Considering that the optimum temperature during estufagem is $45^{\circ} \mathrm{C}$ (Oliveira e Silva et al., 2008), the wines under study were also submitted to a $55{ }^{\circ} \mathrm{C}$ heating temperature (overheating temperature). This temperature was considered high enough to produce significant differences relating to the $45^{\circ} \mathrm{C}$, but not so high to promote the appearance of organoleptic defects. Table 1 briefly displays data on the experiment.

The baking step was carried out in a special pilot scale system equipped with $200 \mathrm{~L}$ stainless steel vats, designed for careful and independent control of temperature by the circulation of hot raw water. The temperature in each vat is continuously monitored and electronically adjusted with deviations less than $2{ }^{\circ} \mathrm{C}$ during the entire experimental period. The system included 10 vats with a similar design to the industrial large vats and was controlled by a PlantWatch software system supplied by CAREL (Padova, Italy).

The wine samples were collected (about $75 \mathrm{cL}$ ) every 30 days and stored at $-20{ }^{\circ} \mathrm{C}$ before analysis. The determination of the basic chemical parameters including the alcoholic strength, $\mathrm{pH}$ and reducing sugar content of the wines in study was performed. The alcoholic strength by volume was carried out according to the usual method of the OIV procedures (OIV, 2000), the $\mathrm{pH}$ was also determined according to the OIV standard procedure (OIV, 2000) while reducing sugars were determined according to the titration method of Lane-Eynon, as described in the Portuguese Official Standards (NP) for Spirits and Alcoholic Beverages (NP2223).

\subsection{Chromatographic analysis}

All samples were analysed by direct injection on a Waters HPLC system equipped with a Waters 1525 Binary HPLC Pump, a Waters 996 DAD and a Waters 717 Plus Autosampler. A Millenium chromatography manager software, version 3.2, was used for data acquisition. Furanic compounds were separated on a Waters

Table 1

Characteristics of the studied wines submitted to the baking step at 30,45 and $55^{\circ} \mathrm{C}$.

\begin{tabular}{|c|c|c|c|c|}
\hline $\begin{array}{l}\text { Grape } \\
\text { variety }\end{array}$ & Method & Abbreviation & Conditions of fermentation & $\begin{array}{l}\text { Sugar } \\
\text { content } \\
(\mathrm{g} / \mathrm{L})\end{array}$ \\
\hline \multirow[t]{3}{*}{ Malvasia } & $\begin{array}{l}\text { Modern } \\
\text { sweet }\end{array}$ & $M \mathrm{~m}$ & $\begin{array}{l}\text { Alcohol is added when density } \\
\text { reaches } 1050 \mathrm{~g} / \mathrm{cm}^{3}\end{array}$ & 78 \\
\hline & $\begin{array}{l}\text { Traditional } \\
\text { sweet }\end{array}$ & Mt & $\begin{array}{l}\text { Alcohol is added after the } \\
\text { beginning of the fermentation }\end{array}$ & 125 \\
\hline & $\begin{array}{l}\text { Modern } \\
\text { dry }^{\mathrm{a}}\end{array}$ & $M m D$ & $\begin{array}{l}\text { Alcohol is added when the } \\
\text { density reaches } 1000 \mathrm{~g} / \mathrm{cm}^{3}\end{array}$ & - \\
\hline \multirow[t]{3}{*}{ Sercial } & $\begin{array}{l}\text { Modern } \\
\text { dry }\end{array}$ & Sm & $\begin{array}{l}\text { Alcohol is added when the } \\
\text { density reaches } 1000 \mathrm{~g} / \mathrm{cm}^{3}\end{array}$ & 16 \\
\hline & $\begin{array}{l}\text { Traditional } \\
\text { dry }\end{array}$ & St & $\begin{array}{l}\text { Alcohol addition after complete } \\
\text { fermentation }\end{array}$ & 0 \\
\hline & $\begin{array}{l}\text { Modern } \\
\text { sweet }^{\mathrm{a}}\end{array}$ & $\mathrm{SmS}$ & $\begin{array}{l}\text { Alcohol is added when the } \\
\text { density reaches } 1050 \mathrm{~g} / \mathrm{cm}^{3}\end{array}$ & - \\
\hline \multirow[t]{4}{*}{$\begin{array}{l}\text { Tinta Negra } \\
\text { Mole }\end{array}$} & $\begin{array}{l}\text { Modern } \\
\text { sweet }\end{array}$ & $T \mathrm{mS}$ & $\begin{array}{l}\text { Alcohol is added when the } \\
\text { density reaches } 1050 \mathrm{~g} / \mathrm{cm}^{3}\end{array}$ & 92 \\
\hline & $\begin{array}{l}\text { Traditional } \\
\text { sweet }\end{array}$ & $\mathrm{TtS}$ & $\begin{array}{l}\text { Alcohol is added after the } \\
\text { beginning of the fermentation }\end{array}$ & 110 \\
\hline & $\begin{array}{l}\text { Modern } \\
\text { dry }\end{array}$ & $T \mathrm{mD}$ & $\begin{array}{l}\text { Alcohol is added when the } \\
\text { density reaches } 1000 \mathrm{~g} / \mathrm{cm}^{3}\end{array}$ & 3 \\
\hline & $\begin{array}{l}\text { Traditional } \\
\text { dry }\end{array}$ & $\mathrm{TtD}$ & $\begin{array}{l}\text { Alcohol addition after complete } \\
\text { fermentation }\end{array}$ & 6 \\
\hline
\end{tabular}

a Only heated at $45^{\circ} \mathrm{C}$.
$150 \mathrm{~mm} \times 3.9 \mathrm{~mm}$ i.d., $4 \mu \mathrm{m}$ Nova-Pak $\mathrm{C}_{18}$ column. The analysis was carried out using an eluent A composed by water-acetic acid-methanol (80:2:18) and an eluent B prepared with the same solvents though comprising the following composition 8:2:90. Gradient elution program was $6 \mathrm{~min}$ at $100 \% \mathrm{~A}$, to $20 \% \mathrm{~A}$ in $4 \mathrm{~min}, 5 \mathrm{~min}$ at $20 \% \mathrm{~A}$, to $100 \% \mathrm{~A}$ in $3 \mathrm{~min}$ and maintenance at $100 \%$ A during $5 \mathrm{~min}$. The flow rate was adjusted to $0.60 \mathrm{~mL} / \mathrm{min}$ and the injected volume was $10 \mu \mathrm{L}$. The DAD was operated with a resolution of $1.2 \mathrm{~nm}$ in the wavelength range of $240-390 \mathrm{~nm}$. The analytes were detected at $280 \mathrm{~nm}$ and identified by superimposing the spectra of each peak with the corresponding spectra of the standards and by comparison of their retention times. Each sample was analysed in triplicate.

\subsection{Validation and quantification}

Quantification was established by means of an external calibration curve. Analytical parameters of the validated methodology are summarised in Table 2. Standard solutions of HMF and $F(1 \mathrm{~g} / \mathrm{L}$ in methanol) were prepared, from which mixtures at different concentrations were made in the range of $2.5-75.0 \mathrm{mg} / \mathrm{L}$, by dilution in ultra-pure water. The curves (five data points, $n=3$ ) were linear with $r^{2}$ values higher than 0.999. The limit of detection (LOD) and the limit of quantification (LOQ) were calculated as follows: $3.3 \sigma / b$ and $10 \sigma / b$, respectively, where $\sigma$ is the $y$-intercept standard deviation and $b$ is the slope of the linear regression. The obtained LOD value was $1.22 \mathrm{mg} / \mathrm{L}$ for both analytes. The method reproducibility and recovery were checked. An RSD of $0.09 \%$ for HMF and $0.15 \%$ for F, and recoveries above $99 \%$ were obtained, when 5 replicates of a Tinta Negra Mole modern dry sample, spiked with $50 \mathrm{mg} / \mathrm{L}$ of $\mathrm{HMF}$ after heating at $55^{\circ} \mathrm{C}$, were injected.

\subsection{Statistics}

All determinations were carried out in triplicate and results were expressed as the mean value \pm standard deviation. Significant differences between wines along heating and the initial state were assessed with analysis of variance (one-way ANOVA with Holm-Sidak post hoc test), using the statistical software SigmaPlot 11.0 for Windows.

\section{Results and discussion}

The initial alcoholic strength of both Malvasia wines was similar, about $17.0 \%(\mathrm{v} / \mathrm{v})$ for Malvasia traditional wine and $17.5 \%(\mathrm{v} / \mathrm{v})$ for Malvasia modern wine. It remained almost constant during the period of the experience. This behaviour was expected as the amount of samples taken was small compared to the total volume in the stainless steel vats, in which the evaporation processes were not significant. Analogous results $(17 \%(\mathrm{v} / \mathrm{v}))$ were observed for Sercial and Tinta Negra Mole wines. The initial pH ranged between 3.41 and 3.57 and showed a small increase with the baking time (about 0.05, after 4 months) but independent of the heating temperature. The total amount of carbohydrates in the studied Madeira wines was also evaluated and initial values are presented in Table 1. Accordingly, Malvasia traditional was the sweetest wine and Sercial traditional was

Table 2

Analytical parameters of the working method.

\begin{tabular}{llll}
\hline & & HMF & $\mathrm{F}$ \\
\hline Concentration range $(\mathrm{mg} / \mathrm{L})$ & & $2.5-75.0$ & $2.5-75.0$ \\
Linear regression $y=b x+a$ & $a$ & 20,173 & $-37,983$ \\
& $b$ & 116,779 & 152,773 \\
$r^{2}$ & & 0.999 & 0.999 \\
LOD & 1.22 & 1.22 \\
LOQ & 3.68 & 3.69 \\
RSD $(\%)(n=5)$ & 0.09 & 0.15 \\
Recovery $(\%)(n=5)$ & 100 & 99 \\
\hline
\end{tabular}


the driest one, as expected due to their specific fermentation conditions and time of fortification.

After the implementation of the conditions described in Section 2.3 it was evidenced that HMF and F eluted after 3.0 and 4.3 min of the analysis, respectively. The validation procedure and the obtained parameters (cf. Table 2) showed that the method was adequate for quantification purposes and could be used to evaluate the F and HMF contents during the baking of the Madeira wines under study. The advantage of the applied RP-HPLC-DAD method was that no additional clean-up methodology was necessary.

As the thermal procedure applied to foodstuff favours the formation of HMF and F, the same can be expected in Madeira wines even if lower temperatures and longer times are used. Ho et al. (1999) determined $\mathrm{F}$ and HMF in several fortified wines including a 10-year-old Verdelho Madeira wine, and the levels found were 8.8 and $361.0 \mathrm{mg} / \mathrm{L}$, respectively. It was concluded that the high value obtained was probably due to the estufagem (the heating stage) process. However, little was undertaken to both evaluate the real impact of temperature and sweetness on the Madeira winemaking process and to define operating conditions for minimisation. In a recent study (Oliveira e Silva et al., 2008), it was determined that the optimal temperature and baking time to obtain a Madeira wine considered typical by an expert panel were $45{ }^{\circ} \mathrm{C}$ and 4 months, respectively. Furthermore, on the basis of AEDA results it was observed that several volatiles usually related to Maillard reactions, such as sotolon, F, 5-methylfurfural, 5-ethoximethylfurfural, methional, and phenylacetaldehyde, were identified as common to both Malvasia and Sercial wines, conferring their typicity. In that study HMF was not identified as a key odorant of Madeira typical wines. Considering that HMF does not improve the characteristics of these wines and can be of some concern when present in higher concentrations in food or beverages, it is important to perform an adequate control and be able to find out the operating conditions for minimizing its levels in these wines.

\subsection{Development of the furanic compounds}

The amount of HMF showed a slight increase (sweet wines) or could not be quantified (dry wines) during the baking conducted at $30{ }^{\circ} \mathrm{C}$. It evidenced final concentrations lower than $12 \mathrm{mg} / \mathrm{L}$. F was found in trace quantities in all wines baked at this temperature. This result suggested that sugar content was not the determinant factor for HMF and $\mathrm{F}$ development in Madeira wines. At higher temperatures, 45 and $55{ }^{\circ} \mathrm{C}$, a continuous growth was verified with heating temperature and baking time (Table 3 ). HMF was reported to appear very high in wines submitted to $55^{\circ} \mathrm{C}$ (overheating temperature), mostly in sweet wines, such as in the traditional Malvasia and Tinta Negra Mole sweet, where $1.2 \mathrm{~g} / \mathrm{L}$ was reached. These results confirmed the high dependence of HMF levels on temperature and time, as is pointed out in different studies. It was evidenced that higher values were obtained for the sweetest wines, particularly when processed by the traditional method, where the sugar content was higher. The estufagem at standard procedures, up to $45^{\circ} \mathrm{C}$, did not promote HMF levels higher than $150 \mathrm{mg} / \mathrm{L}$, even for non-fermented musts where the content in residual sugars remained high. So, the obtained results indicated that the formation of HMF can be controlled during estufagem if the temperature is carefully adjusted and maintained below $45^{\circ} \mathrm{C}$. At higher temperatures the increase of HMF formation in sweet wines was very important, attaining an amount 10 times higher with a $10^{\circ} \mathrm{C}$ increase of the heating temperature. $\mathrm{F}$ was also reported to increase during the test yet important changes were only detected at overheating conditions $\left(55^{\circ} \mathrm{C}\right)$, with slight variations observed between the two vinification procedures when the resulting wines were heated at $45^{\circ} \mathrm{C}$ (e.g. 8.47 and $5.82 \mathrm{mg} / \mathrm{L}$ for Malvasia modern and

Table 3

HMF and F concentrations (mg/L) found in the studied wines submitted to heating at 30,45 and $55^{\circ} \mathrm{C}$.

\begin{tabular}{|c|c|c|c|c|c|c|c|c|}
\hline \multirow[t]{2}{*}{ Means $\pm S D$} & & & \multicolumn{3}{|l|}{ HMF } & \multicolumn{3}{|l|}{$\mathrm{F}$} \\
\hline & & & $30{ }^{\circ} \mathrm{C}$ & $45^{\circ} \mathrm{C}$ & $55^{\circ} \mathrm{C}$ & $30^{\circ} \mathrm{C}$ & $45^{\circ} \mathrm{C}$ & $55^{\circ} \mathrm{C}$ \\
\hline \multirow[t]{15}{*}{ Dry wines } & $T \mathrm{mD}$ & Initial & tr. & tr. & tr. & n.d. & n.d. & n.d. \\
\hline & & $2 \mathrm{M}$ & tr. & $3.72 \pm 0.01^{*}$ & $13.33 \pm 0.04^{*}$ & n.d. & tr. & $4.87 \pm 0.03^{*}$ \\
\hline & & $4 \mathrm{M}$ & tr. & $9.02 \pm 0.04^{*}$ & $15.83 \pm 0.01^{*}$ & n.d. & tr. & $6.85 \pm 0.05^{*}$ \\
\hline & $T \mathrm{tD}$ & Initial & tr. & tr. & tr. & n.d. & n.d. & n.d. \\
\hline & & $2 \mathrm{M}$ & tr. & $4.15 \pm 0.02^{*}$ & $23.50 \pm 0.12^{*}$ & n.d. & tr. & $5.90 \pm 0.04^{*}$ \\
\hline & & $4 \mathrm{M}$ & tr. & $6.21 \pm 0.04^{*}$ & $42.27 \pm 0.19^{*}$ & n.d. & tr. & $9.29 \pm 0.06^{*}$ \\
\hline & Sm & Initial & n.d. & n.d. & n.d. & n.d. & n.d. & n.d. \\
\hline & & $2 \mathrm{M}$ & $5.90 \pm 0.01^{*}$ & $21.13 \pm 0.16^{*}$ & $83.51 \pm 0.09^{*}$ & tr. & $4.19 \pm 0.02^{*}$ & $12.56 \pm 0.00^{*}$ \\
\hline & & $4 \mathrm{M}$ & $6.10 \pm 0.04^{*}$ & $28.78 \pm 0.12^{*}$ & $189.05 \pm 0.60^{*}$ & tr. & $7.01 \pm 0.07^{*}$ & $11.71 \pm 0.12^{*}$ \\
\hline & St & Initial & n.d. & n.d. & n.d. & n.d. & n.d. & n.d. \\
\hline & & $2 \mathrm{M}$ & tr. & $5.39 \pm 0.01^{*}$ & $14.24 \pm 0.05^{*}$ & n.d. & tr. & $5.53 \pm 0.03^{*}$ \\
\hline & & $4 \mathrm{M}$ & tr. & $10.01 \pm 0.02^{*}$ & $19.63 \pm 0.27^{*}$ & tr. & $3.82 \pm 0.02^{*}$ & $8.08 \pm 0.14^{*}$ \\
\hline & $M \mathrm{mD}$ & Initial & - & tr. & - & - & n.d. & - \\
\hline & & $2 \mathrm{M}$ & & tr. & & & tr. & \\
\hline & & $4 \mathrm{M}$ & & $3.68 \pm 0.04^{*}$ & & & tr. & \\
\hline \multirow[t]{15}{*}{ Sweet wines } & $T \mathrm{mS}$ & Initial & $5.67 \pm 0.03$ & $5.67 \pm 0.03$ & $5.67 \pm 0.03$ & tr. & tr. & tr. \\
\hline & & $2 \mathrm{M}$ & $7.63 \pm 0.05^{*}$ & $40.06 \pm 0.61^{*}$ & $558.05 \pm 0.75^{*}$ & tr. & tr. & $11.35 \pm 0.03^{*}$ \\
\hline & & $4 \mathrm{M}$ & $8.62 \pm 0.09^{*}$ & $95.37 \pm 0.16^{*}$ & $976.32 \pm 6.76^{*}$ & tr. & $5.45 \pm 0.03^{*}$ & $18.09 \pm 0.06^{*}$ \\
\hline & $\mathrm{TtS}$ & Initial & $5.97 \pm 0.22$ & $5.97 \pm 0.22$ & $5.97 \pm 0.22$ & n.d. & n.d. & n.d. \\
\hline & & $2 \mathrm{M}$ & $7.63 \pm 0.05^{*}$ & $58.00 \pm 0.18^{*}$ & $637.97 \pm 1.49^{*}$ & tr. & tr. & $11.22 \pm 0.14^{*}$ \\
\hline & & $4 \mathrm{M}$ & $10.90 \pm 0.04^{*}$ & $141.48 \pm 0.29^{*}$ & $1249.24 \pm 0.17^{*}$ & tr. & $4.24 \pm 0.06^{*}$ & $21.29 \pm 0.15^{*}$ \\
\hline & $M \mathrm{~m}$ & Initial & n.d. & n.d. & n.d. & n.d. & n.d. & n.d. \\
\hline & & $2 \mathrm{M}$ & $5.53 \pm 0.08^{*}$ & $55.12 \pm 0.31^{*}$ & $257.65 \pm 0.74^{*}$ & tr. & $3.93 \pm 0.03^{*}$ & $8.32 \pm 0.07^{*}$ \\
\hline & & $4 \mathrm{M}$ & $9.56 \pm 0.12^{*}$ & $136.65 \pm 0.08^{*}$ & $874.23 \pm 5.54^{*}$ & tr. & $8.47 \pm 0.03^{*}$ & $22.90 \pm 0.36^{*}$ \\
\hline & Mt & Initial & tr. & tr. & tr. & n.d. & n.d. & n.d. \\
\hline & & $2 \mathrm{M}$ & $2.49 \pm 0.08^{*}$ & $39.16 \pm 0.09^{*}$ & $354.55 \pm 0.14^{*}$ & tr. & tr. & $6.98 \pm 0.04^{*}$ \\
\hline & & $4 \mathrm{M}$ & $11.54 \pm 0.02^{*}$ & $148.95 \pm 0.23^{*}$ & $1247.80 \pm 1.08^{*}$ & tr. & $5.82 \pm 0.01^{*}$ & $16.33 \pm 0.15^{*}$ \\
\hline & SmS & Initial & - & $4.11 \pm 0.01$ & - & - & n.d. & - \\
\hline & & $2 \mathrm{M}$ & & $29.94 \pm 0.03^{*}$ & & & tr. & \\
\hline & & $4 \mathrm{M}$ & & $67.91 \pm 0.05^{*}$ & & & tr. & \\
\hline
\end{tabular}

2M, 2 months of heating; n.d., not detected, below LOD; 4M, 4 months of heating; SD, standard deviation; tr., trace amounts below LOQ.

* $p<0.001$, significant differences were detected when compared with the initial state.

Concentrations at the end of the heating stage ( 4 months) are indicated in bold. 
traditional wines, respectively). At overheating conditions, $\mathrm{F}$ reached in average $19.65 \mathrm{mg} / \mathrm{L}$ in sweet wines and $8.98 \mathrm{mg} / \mathrm{L}$ in dry ones. Malvasia modern wine baked at $55{ }^{\circ} \mathrm{C}$ had the lowest reducing sugar level of the sweet wines but presented the highest level in $\mathrm{F}$, showing that $\mathrm{F}$ amount cannot easily correlated with the sweetness of the wine. Under these conditions, the formation of $\mathrm{F}$ and HMF in dry wines was observed but remained low, with the exception of Sercial modern dry wine $(189.05 \mathrm{mg} / \mathrm{L}$ and $11.71 \mathrm{mg} / \mathrm{L}$, for $\mathrm{HMF}$ and $\mathrm{F}$ respectively) explained by the highest level of residual sugars between the dry wines under study. Câmara, Marques, Alves, and Silva Ferreira (2004) showed that furanic aldehydes present a linear behaviour with the ageing of Madeira wines undergone in wood casks. The same seems to be valid for the wines submitted to estufagem up to $45^{\circ} \mathrm{C}$, with sweet wines showing an important increase at higher temperatures. This temperature was considered following the organoleptic analysis carried out by an expert panel. It concluded that the typical characteristics of Madeira wine are achieved by estufagem whenever samples are baked at $45^{\circ} \mathrm{C}$ for 4 months (Oliveira e Silva et al., 2008). Therefore, the present study included the comparison with two experimental wines: a dry Malvasia and a sweet Sercial (both wines are not commercially produced) heated at $45{ }^{\circ} \mathrm{C}$ for 4 months. Results showed that Sercial sweet wine presented the same behaviour as other wines produced at similar conditions, though HMF evolution was less extended, not exceeding the $67.91 \mathrm{mg} / \mathrm{L}$. This result is consistent with the lower sugar potential of Sercial grapes; for this reason it is traditionally used for dry wines. In the case of Malvasia dry wine, the amount of HMF was rather low $3.68 \mathrm{mg} / \mathrm{L}$, and similar or lower than other dry wines. F amount was not high enough to be quantified in both wines.

The main sugars present in grapes are glucose and fructose (hexoses), usually in similar amounts at harvest time. Although both decrease during fermentation, their ratio in musts depends on the conditions of the process, since glucose is consumed by the great majority of yeasts prior to fructose (Sanz \& Martínez-Castro, 2009). Thus, when the fermentation of sweet wines is halted by fortification high amounts of glucose, fructose and others residual sugars are still present. So in this kind of wines the high amounts of HMF can be confirmed by glucose and fructose degradation essentially carried out by acidic dehydration, especially when higher temperatures are used in the winemaking process. F occurrence may indicate the existence of pentoses in these wines. These kinds of carbohydrates are not fermentable by yeast, which may explain the observed formation of $\mathrm{F}$ in dry wines heated at higher temperatures. It was also observed that HMF levels were always relatively higher than F, even when wines were completely fermented (traditional dry wines).

To understand which sugar contributes the most to the HMF formation, a simple test was carried out: an $18 \%(\mathrm{v} / \mathrm{v})$ hydroalcoholic solution containing $125 \mathrm{~g} / \mathrm{L}$ of fructose and another with equal amount of glucose were heated at $50{ }^{\circ} \mathrm{C}$ during 75 days. This preliminary test showed that the fructose solution produced 46 times more HMF than the glucose solution, attaining the amount of $226.41 \mathrm{mg} / \mathrm{L}$. This may be due to the fact that fructose naturally exists in higher proportion in the open-chain form than glucose does, and easily dehydrates. Further studies should be conducted taking into account other factors likely to influence sugar degradation during the estufagem of the wines.

\subsection{Assessment of the furanic compounds in commercial wines}

The study was also extended to commercially available Madeira wines in order to evaluate $\mathrm{F}$ and HMF contents found in the market (from different producers). So it covered not only samples which might be submitted to estufagem (most 3-year-old wines) but also those which followed canteiro ageing (below $30^{\circ} \mathrm{C}$ ). Thus, the study analysed 24 samples from dry to sweet wines. Table 4 shows the obtained results and evidence points to the fact that commercial
Table 4

HMF and F contents ( $\mathrm{mg} / \mathrm{L}$ ) found in commercial Madeira wines.

\begin{tabular}{llrl}
\hline Commercial samples & \multicolumn{1}{c}{ HMF } & F \\
\hline 3 years old & Dry 1 & $27.95 \pm 0.31$ & n.q. \\
& Dry 2 & $4.80 \pm 0.06$ & n.d. \\
& Medium dry 1 & $14.36 \pm 0.03$ & n.q. \\
& Medium dry 2 & $5.85 \pm 0.04$ & n.d. \\
& Medium sweet 1 & $60.32 \pm 0.20$ & n.q. \\
& Medium sweet 2 & $6.83 \pm 0.30$ & n.d. \\
& Sweet 1 & $90.95 \pm 0.19$ & $3.82 \pm 0.01$ \\
& Sweet 2 & $6.71 \pm 0.24$ & n.d. \\
Dry 1 (Sercial) & $21.95 \pm 0.02$ & n.q. \\
& Dry 2 & $29.87 \pm 0.07$ & $3.97 \pm 0.28$ \\
& Medium dry 1 (Verdelho) & $30.70 \pm 0.29$ & n.q. \\
& Medium dry 2 & $36.18 \pm 0.05$ & $4.11 \pm 0.02$ \\
& Medium sweet 1 (Boal) & $38.90 \pm 0.20$ & $3.97 \pm 0.04$ \\
& Medium sweet 2 & $20.45 \pm 0.05$ & n.q. \\
& Sweet 1 (Malvasia) & $70.83 \pm 0.07$ & $4.98 \pm 0.06$ \\
& Sweet 2 & $39.84 \pm 0.07$ & n.q. \\
& Dry 1 (Sercial) & $40.57 \pm 0.16$ & $4.60 \pm 0.02$ \\
& Dry 2 & $367.39 \pm 1.32$ & $8.29 \pm 0.01$ \\
& Medium dry 1 (Verdelho) & $59.63 \pm 0.11$ & $5.40 \pm 0.08$ \\
& Medium dry 2 & $195.57 \pm 0.40$ & $6.87 \pm 0.47$ \\
& Medium sweet 1 (Boal) & $48.07 \pm 0.03$ & $6.65 \pm 0.09$ \\
& Medium sweet 2 & $491.90 \pm 1.72$ & $11.55 \pm 0.13$ \\
& Sweet 1 (Malvasia) & $150.41 \pm 1.11$ & $8.31 \pm 0.07$ \\
& Sweet 2 & $287.43 \pm 2.21$ & $9.77 \pm 0.50$ \\
\hline
\end{tabular}

n.q., under LOQ; n.d., not detected or under LOD.

wines under 5 years old presented relatively low amounts of HMF and $\mathrm{F}$, less than $91 \mathrm{mg} / \mathrm{L}$ and $5 \mathrm{mg} / \mathrm{L}$, respectively. The highest amounts were found in sweet wines but those submitted to estufagem (presented in the table without reference to the variety) did not show significant differences to the wines submitted to canteiro ageing (variety indicated in the table). The 10-year-old wines, prepared before current studies were carried out, showed higher amounts of HMF (4 samples with more than $100 \mathrm{mg} / \mathrm{L}$, corresponding to wines submitted to the heating stage before ageing). Even considering that HMF can increase with ageing, the high amounts detected in commercial wines were essentially the result of the initial heating stage, pointing out that the level can be controlled using adequate conditions of estufagem $\left(45^{\circ} \mathrm{C}\right)$. This was also confirmed by the lower values obtained in sweet wines aged in casks (canteiro).

\section{Conclusions}

A validated method was used with success for the evaluation of HMF and $\mathrm{F}$ contents in Madeira wines submitted to prolonged heating. The amount of HMF tended to increase with heating and ageing, where important amounts (greater than $1 \mathrm{~g} / \mathrm{L}$ ) were formed in sweet wines submitted to overheating conditions $\left(55^{\circ} \mathrm{C}\right)$ after a 4-month period. The study clearly showed that the amounts of HMF and $\mathrm{F}$ formed in sweet wines, fermented in order to reduce the amount of residual sugars and baked at temperatures not higher than $45^{\circ} \mathrm{C}$, are under control even for longer ageing periods. On the contrary, dry wines can be fermented in order to maintain a low level of residual sugars, in order to induce the formation of some typical aromas resulting from sugar degradation, and heated up to $45^{\circ} \mathrm{C}$ without a significant increase of the final amount of furans.

The heating process known as estufagem, used in the production of Madeira wines since 1795, is associated to the bouquet of these fortified wines and may play an important role in their exceptional longevity. Heating conditions can be adjusted in order to maintain these important characteristics without compromising the final amount of HMF and contributing to improve general quality. The observed tendency to enhance modern wines, as resulting from organoleptic analysis and HMF evolution data, clearly suggests the importance of the changes being introduced in the fermentation process (sweetness) and baking (temperature). The results also 
showed that dry and sweet wines should not necessarily be heated at the same conditions, with dry wines having lower evolution and supporting higher temperatures. This conclusion can suggest changes in the differentiation of heating conditions applied to different wines, in accordance with the general idea that Sercial wines need extended ageing periods for attaining typicity.

\section{Acknowledgments}

This work was supported by project IMPACT, funded by the Agência de Inovação. Vanda Pereira was supported by Fundação para a Ciência e Tecnologia, PhD grant SFRH/BD/24177/2005.

\section{References}

Adams, T. B., Doull, J., Goodman, J. I., Munro, I. C., Newberne, P., Portoghese, P. S., et al. (1997). The FEMA GRAS assessment of furfural used as a flavour ingredient. Food and Chemical Toxicology, 35(8), 739-751.

Antonelli, A., Chinnici, F., \& Masino, F. (2004). Heat-induced chemical modification of grape must as related to its concentration during the production of traditional balsamic vinegar: A preliminary approach. Food Chemistry, 88(1), 63-68.

Belitz, H. -D., Grosch, W., \& Schieberle, P. (2009). Carbohydrates. Food Chemistry (pp. 248-339). Berlin Heidelberg: Springer.

Câmara, J. S., Marques, J. C., Alves, M. A., \& Silva Ferreira, A. C. (2004). 3-Hydroxy-4, 5dimethyl-2(5H)-furanone levels in fortified Madeira wines: Relationship to sugar content. Journal of Agricultural and Food Chemistry, 52(22), 6765-6769.

Cutzach, I., Chatonnet, P., \& Dubourdieu, D. (1999). Study of the formation mechanisms of some volatile compounds during the aging of sweet fortified wines. Journal of Agricultural and Food Chemistry, 47(7), 2837-2846.

Durling, L. J. K., Busk, L., \& Hellman, B. E. (2009). Evaluation of the DNA damaging effect of the heat-induced food toxicant 5-hydroxymethylfurfural (HMF) in various cell lines with different activities of sulfotransferases. Food and Chemical Toxicology, 47 (4), 880-884

Falcone, P. M., Tagliazucchi, D., Verzelloni, E., \& Giudici, P. (2010). Sugar conversion induced by the application of heat to grape must. Journal of Agricultural and Food Chemistry, 58(15), 8680-8691.
Gökmen, V., \& Acar, J. (1999). Simultaneous determination of 5-hydroxymethylfurfural and patulin in apple juice by reversed-phase liquid chromatography. Journal of Chromatography A, 847(1-2), 69-74

Granados, J. Q., Mir, M. V., Serrana, H. L. G., \& Martinez, M. C. L. (1996). The influence of added caramel on furanic aldehyde content of matured brandies. Food Chemistry, 56 (4), 415-419.

Ho, P., Hogg, T. A., \& Silva, M. C. M. (1999). Application of a liquid chromatographic method for the determination of phenolic compounds and furans in fortified wines. Food Chemistry, 64(1), 115-122.

Janzowski, C., Glaab, V., Samimi, E., Schlatter, J., \& Eisenbrand, G. (2000). 5Hydroxymethylfurfural: Assessment of mutagenicity, DNA-damaging potential and reactivity towards cellular glutathione. Food and Chemical Toxicology, 38(9), $801-809$

Li,, Y. -h., \& Lu, X. -y. (2005). Investigation on the origin of 5-HMF in Shengmaiyin decoction by RP-HPLC method. Journal of Zhejiang University - Science B, 6(10), 1015-1021.

Lo Coco, F., Valentini, C., Novelli, V., \& Ceccon, L. (1995). Liquid chromatographic determination of 2-furaldehyde and 5-hydroxymethyl-2-furaldehyde in beer. Analytica Chimica Acta, 306(1), 57-64.

Monien, B. H., Frank, H., Seidel, A., \& Glatt, H. (2009). Conversion of the common food constituent 5-hydroxymethylfurfural into a mutagenic and carcinogenic sulfuric acid ester in the mouse in vivo. Chemical Research in Toxicology, 22(6), $1123-1128$.

Nassberger, L. (1990). Influence of 5-hydroxymethylfurfural (5-HMF) on the overal metabolism of human blood cells. Human E Experimental Toxicology, 9(4), $211-214$.

OIV (2000). Recueil des methods internationals d'analyse des vins et des moûts. Paris: Organisation Internationale de la Vigne et du Vin.

Oliveira e Silva, H., Guedes de Pinho, P. Machado, B. P. Hogg, T., Marques, J. C. Câmara, J. S., et al. (2008). Impact of forced-aging process on Madeira wine flavor. Journal of Agricultural and Food Chemistry, 56(24), 11989-11996.

Sanz, M. L., \& Martínez-Castro, I. (2009). Carbohydrates. In M. V., \& M. C. (Eds.), Wine Chemistry and Biochemistry (pp. 231-248). New York: Springer.

Surh, Y. -J., Liem, A., Miller, J. A., \& Tannenbaum, S. R. (1994). 5-Sulfooxymethylfurfural as a possible ultimate mutagenic and carcinogenic metabolite of the Maillard reaction product, 5-hydroxymethylfurfural. Carcinogenesis, 15(10), 2375-2377.

Zhang, X. -M., Chan, C. C., Stamp, D., Minkin, S. C., Archer, M., \& Bruce, W. R. (1993). Initiation and promotion of colonic aberrant crypt foci in rats by 5-hydroxymethy12-furaldehyde in thermolyzed sucrose. Carcinogenesis, 14(4), 773-775. 